\title{
USE OF RFID TECHNOLOGY IN THE IDENTIFICATION, STORAGE, CONTROL AND MOVEMENT OF ELECTRONIC URNES
}

\section{${ }^{*}$ Igor Gomes de Lucena, ${ }^{1}$ Maurisergio Ferreira de Aquino filho, ${ }^{1}$ Bruno Pereira Gonçalves, ${ }^{1}$ Jean Mark Lobo de Oliveira, ${ }^{2}$ Benevaldo Pereira Gonçalves and ${ }^{3}$ David Barbosa de Alencar}

\author{
1Engineering Department of FAMETRO University Center, Amazon-Brazil \\ ${ }^{2}$ Federal Institute of Educational, Science and Technology of Amazonas - IFAM, Brazil \\ ${ }^{3}$ Institute of Technology and Education Galileo of Amazon (ITEGAM), Brazil
}

\section{ARTICLE INFO}

\section{Article History:}

Received $19^{\text {th }}$ December, 2019

Received in revised form

$20^{\text {th }}$ January, 2020

Accepted $02^{\text {nd }}$ February, 2020

Published online $31^{\text {st }}$ March, 2020

\section{Key Words:}

Electoral justice; Electronic Urn; Information security; Radio frequency.

*Corresponding author: Igor Gomes de Lucena,

\begin{abstract}
This article brings an important part of Electoral Justice: the Electronic Ballot Box. The importance of the Electronic Ballot Box in the Electoral process is of great importance, as it provides a change in the process of receiving votes (representing the will of the voter), providing greater speed and security, in addition to the totalization and dissemination of those elected within a few hours, which used to take days. Despite this evolution, the identification and storage of Electronic Ballot Boxes takes place in a traditional way, stacked on pallets and discarded in deposits in the Electronic Ballot Box Section. What makes a search for a specific urn, a work task and collapsed. In this item, we propose the use of radio frequency identification - RFID as an alternative for the identification and control of electronic voting machines, promoting intelligent storage that allows, in addition to the identification and location of the electronic ballot box, an umbrella of useful information from the electronic ballot box.
\end{abstract}

Copyright (C) 2020, Igor Gomes de Lucena et al. This is an open access article distributed under the Creative Commons Attribution License, which permits unrestricted use, distribution, and reproduction in any medium, provided the original work is properly cited.

Citation: Igor Gomes de Lucena, Maurisergio Ferreira de Aquino filho, Bruno Pereira Gonçalves et al. 2020. “As narrativas orais e o letramento no registro de um escutador de histórias", International Journal of Development Research, 10, (03), 34627-34630.

\section{INTRODUCTION}

More and more organizations are adapting their processes to better use time, reduce costs and, consequently, increase their competitiveness. In this challenge, business logistics takes on special importance in adding value to an organization's products or services, by defining flows, storage and movement of products in a more efficient way, ensuring that they are available in time, place and conditions appropriate to satisfaction of customers' wishes. In organizations that provide public services that, unlike private organizations, do not have the objective of producing wealth, logistics plays an important role in efforts to "better spend people's money". KOHAMA (2006, p. 09) states that "In the state sector, to administer is to manage public resources. In other words, it means not only providing service and / or executing it, but also directing, governing, exercising will with objective of obtaining a useful result for society ". The logistics in the public organization, in addition to serving at the right time and place, in appropriate conditions and forms, must be done in an economically efficient, effective and effective way for adequate and responsible use of resources. public. In any organization, Information Technology (IT) has great relevance in the implementation of efficient processes. In logistics, the use of IT tools adds value to your methods, optimizes time and reduces costs. Among the IT tools used to optimize logistical processes, Radio Frequency Identification (RFID) has been gaining notoriety for promoting the collection and storage of information with greater efficiency, helping in decision making.

Electoral Justice: The Electoral Justice is a public body of Specialized Justice of the Federal Judiciary, whose Mission is "To guarantee the legitimacy of the electoral process and the free exercise of the right to vote and be voted, in order to strengthen democracy". To fulfill this Mission, it uses the Electronic Ballot Boxes to collect voters' votes, in the General Elections (where the President, Senators, Governors and Federal and State Deputies are elected) and Municipal Elections (where the Mayors are elected) and Councilors) and many other IT tools, in addition to the framework for the 
processing and totalization of votes, in order to ensure that the popular will is carried out and guaranteed.

Logistics: In Strategic Management, Logistics has great relevance for connecting the organization to suppliers and customers through planning processes, flow control and storage of products and services, from origin to delivery to the customer. According to SALES, (2000, p. 57) "Logistics is the search to optimize the activities of order processing, dimensioning and control of inventories, transportation, storage and handling of materials, packaging projects, purchases and management of information related to the activities in order to provide value and a better level of customer service".

Information Technology: Information Technology is a powerful tool for organizations, being responsible for the processing of information (the most valuable asset of organizations), helping decision making. According to Cruz, (2010, p.26), "Information Technology is any and all devices that have ability to treat and or process data or information, both systemically and sporadically, whether applied to the product or applied to the process ". The use of IT tools in Logistics provides optimization of the registration and control of information and storage processes.

\section{MATERIALS AND METHODS EXPERIENCES}

Electronic Urn: The Electronic Ballot Box is the tool introduced by the Electoral Justice after the 1996 elections, to receive voters' votes in choosing their representatives, both in the Official Elections and in the Unofficial Elections, such as those for choosing Class Representatives (CREA, OAB, etc.), of the Rector and Councilors of Universities, of union leaders, among others. Electronicurn innovated the Elections, providing greater speed and efficiency in receiving votes, totaling and, consequently, in the dissemination of results. An even greater benefit is the fact that it prevents fraud in voting and that it has "zeroed" human errors during the totalization of votes, ensuring the smoothness of the election. TRE-AM has 10,294 Electronic Urns, the model of which refers to the year of manufacture. Of these, the following 03 (three) were used:

Table 1.0 Electronic voting machines by model, used in the 2012, 2014 and 2016 elections

\begin{tabular}{|c|c|c|c|c|c|c|}
\hline \multirow{2}{*}{ Plead } & \multicolumn{7}{|c|}{ Models } \\
\cline { 2 - 7 } & 2009 & 2010 & 2011 & 2013 & 2015 & Total \\
\hline 2012 & 1951 & 2793 & 972 & - & - & 7272 \\
\hline 2014 & 2187 & 3629 & - & 201 & - & 7264 \\
\hline 2016 & 1610 & 2740 & 790 & - & 2159 & 7299 \\
\hline
\end{tabular}

Storage and Movement of Electronic Urns: In Amazonas, the Regional Electoral Court is responsible for receiving, guarding and handling the Electronic Ballot Boxes that are used to hold the Elections. These, after receipt and registration of your identification, through registration plates, are stored in a centralized deposit, located in the annex building of its headquarters. The entire process of receiving, accepting, identifying, tipping, guarding and handling is done manually, by employees who assess their physical condition, plan the information, record the tipping and store it in the Electronic Ballot Box. Subsequently, the spreadsheet is forwarded to the Heritage Section for registration of acceptance and registration in its database. The Electronic Ballot Boxes are periodically moved for testing and simulations, Unofficial Elections and
Official Elections. In both processes, movement control is done in spreadsheets.

Loading and Sealing Ceremony: Go through the process of preparing the Electronic Ballot Boxes for an Election, official or not. These are selected and transported from the storage area in the Electronic Ballot Box deposit, according to the models and quantities described in the event planning, subject to availability, to the benches, where they are unpacked and checked for physical and cleanliness. Afterwards, already installed in the stands, the hardware and software tests that compose it are carried out and, without any problem, the Election applications and the files of candidates and voters of the Electoral Section are installed. Once this stage is concluded, the electronic urn receives labels that identify it in relation to the respective Section and Electoral Zone, then it is sent to the seal and packaging counter, where it receives the seals related to the Election in vogue and is packed in an identified box, also in in relation to the respective Electoral Section and Zone. Finally, they are delivered to the Electronic Ballot Box Logistics Commission - CLUE, which, after a thorough check of the quantities, organized by electoral zone, place of voting and electoral section, for later forwarding to the respective electoral office. According to Rodrigo Carvalho, Infrastructure Coordinator at TRE-AM and one of those responsible for the deposit and logistics of Electronic Ballot Boxes, the average time for checking a pallet with 48 (fortyeight) units and registration in a spreadsheet exceeds 20 minutes. This procedure is done through the visual identification of the registration plate and the identification label of Section, Voting Place and Electoral Zone.

Transportation to Electoral Areas and Voting Places: Once the electronic ballot loading and sealing stage is closed, CLUE is responsible for distributing these to the Electoral Registry. In this stage, the timing with the Electronic Ballot Box, the Notaries and the Post Office, obeys the pre-established criteria according to the distance, storage capacity and transport conditions of each Electoral Office, to avoid failures, delays or mistakes in transportation or destination of the Electronic Ballot Boxes.

\section{RFID - Radio Frequency Identification}

History: Used in World War II, according to Roberti (2005), to locate airplanes, the radar system was developed in 1935 by Sir Robert Alexander Watson-Watt and improved to identify friendly planes that were equipped with transmitters that sent signals to radars in ground. In 1999, the Massachusetts Institute of Technology, in conjunction with other research centers, developed the Electronic Product Code - EPC, defining an architecture for identifying products through the use of radio frequency signals. Currently, Radio Frequency Identification (RFID) is used in several applications in different segments such as aircraft manufacturers, security, logistics and other applications.

Architecture: An RFID system is formed by tags (TAGs) or transponders that contain a chip with an antenna that can be tracked by radio frequency, a reader that sends electromagnetic waves that are detected by the TAG and, after being processed by the chip, responds to the reader, and a controller is responsible for processing the information. 


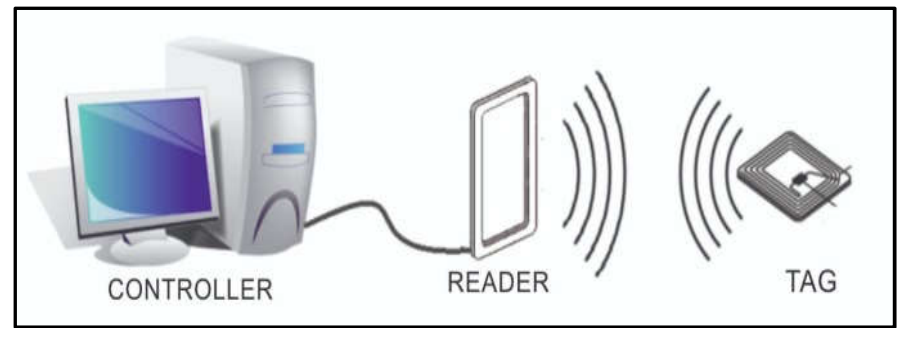

Figure 1. Components Identifier, Tags or Transponder

The components presented are the controllers, readers and tags.

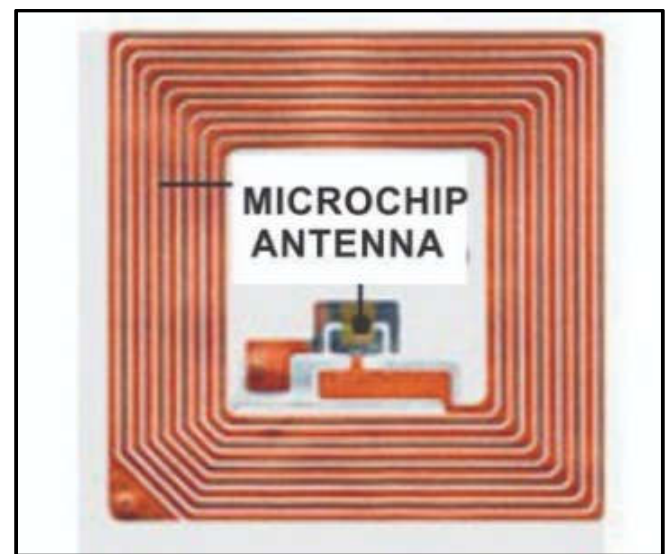

Figure 2. Microchip model

It is a device for storing data about an object. It consists of a microchip for the storage of information, which can be readonly, one written and several readings or totally rewritable, and an antenna for transmitting the information. According to Bhatt \& Glover (2007), they are classified according to: Formats and sizes, which allows them to better adapt to the object to be monitored; Energy source, where they can be classified, according to Santini (2006), in:o Passive - they are fed by electromagnetic waves emitted by the reader antenna, being inactive when in their absence, being read only and used at a short distance;

- Semi-passive - they have a battery to power the internal circuits, but they use the energy of the reader to carry out the communication;

- Active - has a capacity to carry out transmission, as it has an internal power source for both power and circuits and for carrying out transmission;

- Two-way - are active identifiers that can communicate with other identifiers.

Frequency, refers to the bands in which the identifiers work, commonly ranging from $100 \mathrm{KHz}$ to $5.8 \mathrm{GHz}$.

The models and applications are divided according to the bands: Or the communication mode can transmit or receive, but not simultaneously (half-duplex) or transmit and receive simultaneously (full-duplex). There are also sequential models, which work only half or duplex, however, sending an energy signal only when sending data.

Table 2. Bands used by RFID

\begin{tabular}{lll}
\hline Band & Reach & Applications \\
\hline Low $-100 \mathrm{Khz}$ & $0,5 \mathrm{~m}$. & Access control. \\
High $-13,5 \mathrm{Mhz}$ & $1 \mathrm{~m}$. & Access and object control. \\
Ultra -860 to $960 \mathrm{Mhz}$ & $12 \mathrm{~m}$. & Object identification. \\
Microwave $-2,45$ to $5,8 \mathrm{Ghz}$ & + de $10 \mathrm{~m}$. & Industrial projects. \\
\hline
\end{tabular}

Storage, varying according to the memory used in the identifier, which can be:

- Read Only, recorded only once by the manufacturer, only allow reading of data from memory. They are indicated for localization purposes or small commercial applications;

- Write Once - Read Many, allow more than one recording and several readings of the memory data;

- $\quad$ Read-Write, these memories allow permanent updates of the recorded data. Indicated for data security and environment monitoring.

Reader or Transceiver: They are devices, with their own power, responsible for the communication between the identifier and the data processing system.

They consist of:

- Antenna, through which it obtains identifier information;

- Controller, responsible for controlling the reader;

- Network interface;API - Application Programming Interface, which communicates the applications with the reader;

- Event management, for managing the identifiers that enter the reader's field;

- Communication system to control protocols.

Readers have different shapes, adapting to applications, the most common being:

- Portals, are gates equipped with a set of antennas to recognize items when passing through them

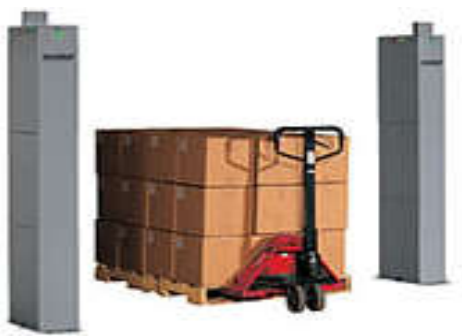

Figure 3. Portals equipped with a set of antennas

Portable devices, for individual reading of objects;

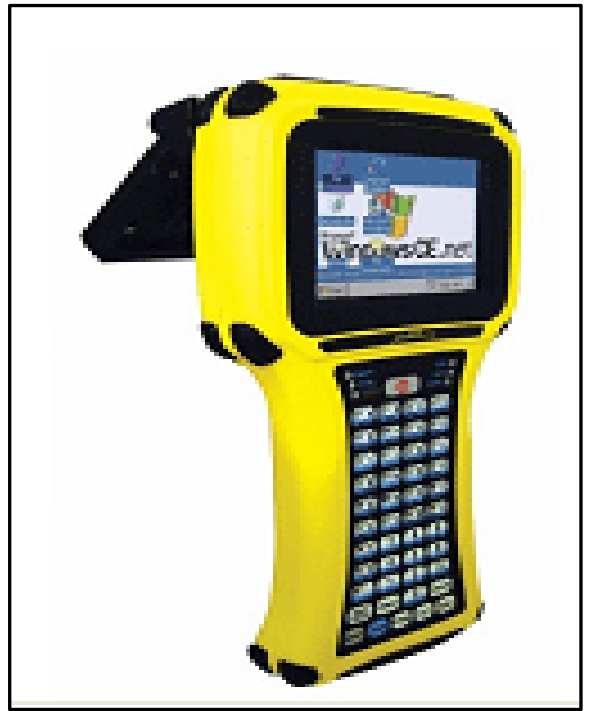

Figure 4. Portable reading devices 
Smart shelves, have antennas built into their structure, allowing the arrival and departure of objects or to read all items at the same time, enabling real-time inventories.

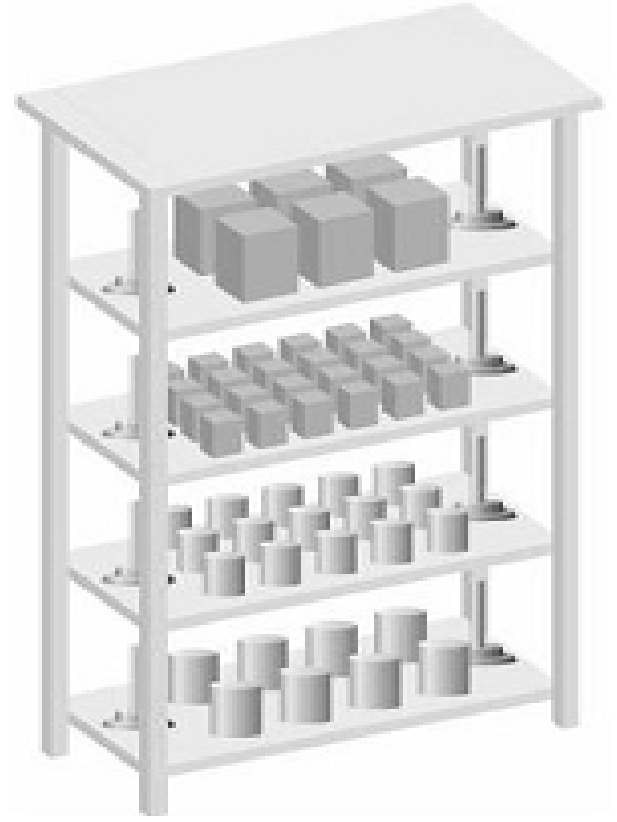

Figure 5. Smart shelves with built-in antennas

Advantages and disadvantages: Soares and Comucci, (2008 p.108) and Slack, (2009 p.229) mention the following advantages:

- $\quad$ Reading data automatically;

- Increased productivity and reduced time and cost;

- Product tracking;

- Inventory optimization;

- Reduced queues and faster service.

- As disadvantages:

- Higher technology cost compared to barcode systems;

- Impact of cost on the final price of products;

- Reading can be impaired by magnetic fields; readinginformation on products, beyond the limits of the cash register, can embarrass customers.

\section{RESULTS}

After the 2014 General Elections, at the request of a political party, an audit was carried out at the Electronic Ballot Boxes that participated in that election. The audit took place by sampling, where, in Amazonas, 45 (forty-five) Electoral Sections were indicated that, according to Herbert Van, one of the coordinators of the Electronic Ballot Box Section, to locate them among the 7,299 Ballot Boxes used in the 2014 Elections, 02 (two) employees took up to 20 minutes to move the pallets, unpack the urns, unpack them and check the identification. Simulation performed with a barcode reader, only when reading the tipping plate, provided a relevant reduction in the identification time. But it would not help much when it comes to identifying items among the entire set of Electronic Ballot Boxes. It was not possible to carry out tests using RFID, however, still the equipment that works in the smallest band, promotes immediate reading of the items and transmission of data to update the information. Which would allow, if used, significant speed in the identification of the Electronic Ballot Boxes.

\section{DISCUSSION OF RESULTS}

The audit showed a problem already perceived in the model used for the storage of Electronic Ballot Boxes. Despite efforts to maintain an organized environment, separating them by model and, when preparing for elections, by electoral zone or grouping of sections that will be used. However, when it is necessary to identify or review a history of a particular Urn, users face difficulties. With a view to improving this model, a tipping plate with barcode was introduced in each Urn. This tipping, during the Loading Ceremony, is associated with the Section it will represent. Despite promoting better control of the Urn and a more efficient reading of the Urns on a pallet, it does not provide a quick location since, for reading the plate, there is still the need to move the pallets. The use of Radio Frequency Identification, in addition to quick reading and obtaining information, allows you to do it wherever they are, without moving the pallets. Technology is the driving force that promotes change in processes, reducing time and cost. In a Specialized Justice, whose deadlines are short and the results are of great relevance to the population, moreefficient and fast add value to your results.

\section{Conclusion}

Old models, although they work, can provide inconveniences as in the event of the location of the Electronic Ballot Box during an audit. The need to make better use of time and reduce costs, moves managers in the search for solutions that give them agility and economy, increasing competitiveness. And it is technology that provides them with these skills. In this article, we can see how RFID technology can optimize the process of identifying, storing and storing information about Electronic Ballot Boxes, optimizing the activities of those who work with them and those who are responsible for their management.

Acknowledgments: To my friends who listened to me while I dreamed of the possibilities that we could propose for this work, to the masters throughout our academic lives and, especially, to our families.

\section{REFERENCES}

A Empresa do Sec. XXI. São Paulo, Atlas, 2010. $3^{\text {a }}$ Ed. SALES, A. S. F.; FERREIRA, M. L. GestãoEstratégica da InformaçãonaLogística. Reúna - Revista de Economia da UNA, v. 7, n. 2, abr./jun.2000, p.25-34.

BHATT, H.; GLOVER, B. Fundamentos de RFID: Rio de Janeiro:Altas Books, 2007.

CRUZ T. Sistemas de InformaçõesGerenciais: Tecnologias da Informação e KOHAMA, Heilio. Contabilidadepública: teoria e prática. 10. ed. São Paulo: Atlas, 2006.

RFID Journal Brasil. Site. PerguntasFrequentes. [2011b]. Disponívelem $<$ http://brasil.rfidjournal.com/perguntasfrequentes $>$ Acessoem 0101 de fevereiro de 2019.

ROBERTI, Mark. The History of RFID Technology. Site RFID Journal. 16 de Jan. 2005. Disponívelem $<$ http://www.rfidjournal.com/articles/view?1338>. Acessoem 29 de março de 2019.

SLACK, Nigel; CHAMBERS, Stuart; JOHNSTON, Robert. Administração da produção. 3. ed. São Paulo: Atlas, 2009.

SOARES, R; COMUCCI, T. et al. O impacto da tecnologia de etiquetainteligente (RFID) na performance de cadeias de suprimentos: Um estudo no Brasil. Mackenzie, São Paulo, p. $101-115$, n. 9 , jul./dez. 2008. 